Journal of Food Technology 8 (3): 134-142, 2010

ISSN: $1684-8462$

(C) Medwell Journals, 2010

\title{
Addition of Some Natural Plant Extracts and their Effects on Lamb Patties Quality
}

\author{
Hayam M. Ibrahim, Azza A. Abou-Arab and Ferial M. Abu Salem \\ Deptartment of Food Technology, National Research Center, Dokki, Cairo, Egypt
}

\begin{abstract}
Optimum concentrations of some natural plants (jojoba, jatropha, ginseng and ginger) extracts were determined and added to lamb patties. Some chemical and microbial characteristics of the prepared patties during storage for 9 days at $4^{\circ} \mathrm{C}$ were evaluated (at $0,3,6$ and 9 days). Both the addition of these extracts and storage time had a significant effect on patties over the storage period. $\mathrm{pH}$ values of control samples were found to be the highest during storage. The effectiveness of the tested natural extracts can be listed in the following order of decreasing TBARS values: ginseng $>$ jatropha $>$ jojoba $>$ ginger. Aerobic plate count, mould and yeast counts decreased significantly $(\mathrm{p}<0.05)$ with addition of the extracts during the storage period. Also, addition of the extracts were effective significantly $(\mathrm{p}<0.05)$ in reducing histamine tyramine and putrescine formation over storage period. Compared to control patties the addition of these natural extracts was effective as antioxidant and antimicrobial agents for improving lamb patties properties from quality and safety view point.
\end{abstract}

Key words: Antimicrobial, antioxidant, biogenic amines, lipid oxidation, lamb patties, microbial counts, natural plant extracts

\section{INTRODUCTION}

Lipid oxidation and growth of undesirable microorganisms in food products results in the development of spoilage, off flavor, rancidity and deterioration, rendering such products unacceptable for human consumption (Bozin et al., 2007) and yielding many compounds that contribute to the pathogenesis of cancer, atherosclerosis, heart and allergic diseases (Mielnik et al., 2008; Tang et al., 2001).

Lipid oxidation is considered as one of the major problems occurring during processing and storage of meat and meat products. Biogenic amines are basic nitrogenous compounds found in a wide variety of foods such as meat and meat products (Vinci and Antonelli, 2002). The presence of biogenic amines in food constitutes a potential public health concern due to their physiological and toxicological effects. It is important to monitor biogenic amine levels in fresh and processed food not only due to their toxicity but also they can be a useful index of spoilage (Onal, 2007).

Lipid oxidation and microbial growth in meat products may be controlled or at least minimized by using either synthetic or natural food additives commonly used in the meat industry (Gray et al., 1996; Lee et al., 1997; Aaby and Skrede, 2003; Salam et al., 2004; Estevez and Cava, 2006).
Natural antioxidants found in plants have gained considerable interest for their role in preventing the auto-oxidation of fats, oils and fat containing food products (Reddy et al., 2005). Antioxidant properties of herbs, spices, plant and other food extracts are apparently related to their phenolic content, suggesting that antioxidant action is similar to that of synthetic phenolic antioxidants (Lai et al., 1991).

Since the worldwide trend towards the use of natural additives in food (Yanishlieva et al., 2006); natural plants are considered as important target to search and give a new source of natural antioxidants and antimicrobial agents from safety view point. Consequently, there is a practical need for screening and selection of natural antioxidants as effective alternatives in the prevention of food deterioration (Kikuzaki and Nakatani, 1993). Several plants exist with very high nutritive value and yet remain unexploited for human and animal benefits (Oladele and Oshodi, 2007). Therefore, the search for and development of other antioxidants and antimicrobial of natural origin are highly desirable.

Jatropha curcas is a nut belonging to the Euphobiaceae family. Recently, the tree of this plant has been successfully cultivated in Upper Egypt (Hawash et al., 2009) and all parts of it have their own uses as cleared by Gubitz et al. (1999) and Makkar et al. (1997). El Diwani et al. (2009) reported that residue of

Corresponding Author: Hayam M. Ibrahim, Deptartment of Food Technology, National Research Center, Dokki, Cairo, Egypt 
methanolic extract of Egyptian jatropha curcas contains bioactive substances such phenolic compounds which succeeded to be used as natural antioxidant against oxidative deterioration.

Jojoba plant, Simmondsia chinensis and related species are evergreen shrubs which grow wild and it is now cultivated commercially in Argentina, Australia, China, Egypt and United States. The flavonoid profile of jojoba fruits may put the family among other families rich in flavonol methyl ethers and flavonoid content make the pericarp a valuable source for antioxidant and hepato-protective compounds (E1-Halawany, 2002). This plant extract has been reported to be useful as a dietary supplement for use in weight control regiment in humans, a component of functional food, a food additive, a medical food or as a therapeutic agent (Teague et al., 2005).

Ginseng is an herbaceous perennial belonging to Aralia family. It is used early for medicinal purposes and used widely in herbal, health food and cosmetic applications (Ramgahau, 2001). In recent years, various formulations prepared from the Panax ginseng roots has been marketed as dietary supplements especially in China which is frequently used as food additives and raw materials of healthy food rather than therapeutic agents (Breemen et al., 1995; Gillis, 1997; Shen et al., 2003). Ginsenosides are triterpenes saponins and considered to be the main bioactive principles of the most important oriental herbal medicine ginseng from the roots and rhizomes of different Panax species (Araliaceae) (Fuzzati, 2004). Bioactive compounds from medicinal plants including ginseng are known to protect against oxidative stress from reactive oxygen species and prevents lipid per-oxidation (Sievenpiper et al., 2003).

The rhizome of the popular ginger species, Zinger officinale is widely used as a spice and food seasoning due to its sweet aroma and pungent taste. It is well known to have antioxidant activity (Jitoe et al., 1992; Zia-ur-Rehman et al., 2003) and effective antimicrobial. The extracts of fresh ginger showed a higher activity than that of stored ginger (Kawamura et al., 1993) and ginger rhizome extract exhibited the highest antioxidant activity (Mansour and Khalil, 2000). Also, the antioxidant effect and the total phenols of ginger extract were studied by Stoilova et al. (2007).

The interest in the antioxidant activity of plant extracts has become larger and very important (Joyeux et al., 1995; Azaizeh et al., 2005; Alma et al., 2003) due to the fact that free radicals e.g., Reactive Oxygen Species (ROS) can be responsible for various diseases e.g. heart diseases, stroke, arteriosclerosis and cancer as well as for aging process (Willcox et al., 2004). The effects of plant extracts or essential oils classified as Greatly Recognized As Safe (GRAS) following their addition have been studied extensively and reported in a variety of meat types including pork (Nissen et al., 2004); beef (Solomakos et al., 2008); lamb (Camo et al., 2008). Lamb meat contains higher levels of $\dot{\omega}-3$ Polyunsaturated Fatty Acids (PUFA's) compared to beef or pork which is beneficial to human health (Wood et al., 1999); however, PUFA's increase the susceptibility of meat to oxidative processes such as lipid oxidation ultimately leading to off odors and warmed over flavor (Jeremiah, 2001).

The present study aimed to determine the optimum concentrations of some natural plant (jojoba, jatropha, ginseng and ginger) extracts as sources of natural antioxidants and antimicrobial agents and adding them during preparing lamb meat patties in order to investigate their effect on Thiobarbituric Acid Reactive Substances (TBARS), Biogenic Amines (BA), pH, Aerobic Plate Count (APC), mould and yeast counts in the prepared patties stored at $4^{\circ} \mathrm{C}$ for 9 days. Hence by which the meat quality could also be assessed.

\section{MATERIALS AND METHODS}

Materials: Four natural plants (Jojoba, jatropha, ginseng and ginger) were used as a source of antioxidants and antimicrobial agents. Jojoba (Pericarp) was purchased from the Egyptian Natural Oils Company, Cairo, Egypt. Jatropha curcas (leaves and roots) were obtained from Ministry of Agriculture and Reclamation Land, Egypt. Jojoba and Jatropha were air-dried, powdered and kept in tightly closed amber glass containers. Ginger rhizomes (Zingiber officinale) were purchased from the local market. Korean red ginseng extract was obtained from Korean Society of ginseng, Seaul, Korea (Prof Dr. Mosaad A. Abdel-Wahhab, Food Toxicology and Contamination Department of National Research Center, Cairo, Egypt). Thiobarbituric Acid (TBA), 1, 1, 3, 3-Tetraethoxypropan (TEP) and other chemicals used were of analytical grade and were obtained from Sigma Chemical Co (St. Louis, $\mathrm{MO})$.

Preparation of jojoba extract: Air-dried powdered pericarp $(1 \mathrm{~kg})$ was exhaustively defatted using hexane and then extracted with ethanol $70 \%$ by percolation. The ethanolic extract was combined and evaporated under reduced pressure to yield $50 \mathrm{~g}$ of dry residue. The residue was suspended in water $(250 \mathrm{~mL})$ and partitioned successively with chloroform $(5 \times 50 \mathrm{~mL})$ followed by ethyl acetate $(5 \times 50 \mathrm{~mL})$ and $\mathrm{n}$-butanol $(7 \times 50 \mathrm{~mL})$. The solvents were evaporated under reduced pressure to give chloroform fraction (11 g), ethyl acetate fraction $(4 \mathrm{~g})$ and butanol fraction (10 g) (El-Halawany, 2002).

Preparation of jatropha extract: About $10 \mathrm{~g}$ of the air-dried powdered of leaves and roots of jatropha was 
extracted successively under shaking with chloroform $\left(\mathrm{CHCl}_{3}\right)$ for 3-5 times at room temperature with $90 \%$ methanol $\left(\mathrm{CH}_{3} \mathrm{OH}\right)$ in water-bath at $50^{\circ} \mathrm{C}$ for 3-5 times and finely with water in a water-bath at $70^{\circ} \mathrm{C}$. The obtained extract was filtered and evaporated by using vacuum evaporator to give the crude dried extract (Mothana and Likdequist, 2005).

Preparation of ginger extract: Ginger rhizomes were ground and passed through a 60 mesh screen. About $100 \mathrm{~g}$ of ground ginger was defatted by shaking 3 times with 4 volumes of petroleum ether in a rotary shaker for $1 \mathrm{~h}$. The residue obtained after filtration was dried overnight under a hood until all traces of petroleum ether were removed. The dried residue was extracted three times with 4 volumes of $90 \%$ ethanol by shaking for $1 \mathrm{~h}$ and filtered. The combined filtrate was concentrated in a rotavapor and placed under a hood to remove the residual ethanol. The obtained aqueous extract was frozen overnight and freeze dried at $-60^{\circ} \mathrm{C}$ (Dura-Dry, USA). The freeze-dried extract was stored in air-tight containers at $5^{\circ} \mathrm{C}$ until used. (Mansour and Khalil, 2000)

Determination of optimum concentration of the natural extracts: Jojoba, jatropha, ginseng and ginger extracts were screened at level ranging from $0-1 \%$ to determine their optimum working concentrations. Optimum concentrations for the individual test extracts were identified during the screening trials and assessed simultaneously. Optimum concentrations of the test extracts determined from TBARS data in the screening trials were incorporated into patties preparation from lamb meat. The potential antioxidants of the test ingredients were determined through Thiobarbituric Acid Reactive Substances (TBARS) which were assessed in the lamb patties.

Preparation of lamb patties: Fresh lamb meat were obtained from a local slaughter house and held overnight at $0^{\circ} \mathrm{C}$. Lamb meat was minced using meat mincer. Minced lamb meat was subdivided into five equal parts. Lamb patties were prepared to provide 5 treatments. Control treatment was formulated without plant extract. The other treatments were prepared by adding the optimum concentrations determined of the tested extracts as follows: $0.1 \%$ jojoba extract (sample 1), $0.1 \%$ jatropha extract (sample 2), $0.25 \%$ ginseng extract (sample 3) and $0.25 \%$ of ginger extract (sample 4 ) then mixed well and formed into patties $(50 \mathrm{~g})$ using a meat former. Lamb patties were placed on plastic foam meat trays, wrapped with polyethylene film and kept in a refrigerator at $4^{\circ} \mathrm{C}$ for 9 days. The effect of optimum concentration of the test ingredients on Thiobarbituric Acid Reactive Substances (TBARS), pH, Biogenic Amines (BA) mould and yeast counts and Aerobic Plate Count (APC) were determined in lamb patties for $0,3,6$ and 9 days of storage time at $\left(4^{\circ} \mathrm{C}\right)$. Hence, by which the patties quality and safety could be assessed.

\section{Chemical analyses}

pH determination: Lamp patty sample $(10 \mathrm{~g})$ was homogenized in $100 \mathrm{~mL}$ distilled water for $1 \mathrm{~min}$ in a blender and the $\mathrm{pH}$ was measured using a digital $\mathrm{pH}$-meter (HAANA, H $\amalg 902$ meter, Germany). Two readings were taken from each of three lamb patty sample.

Thiobarbituric Acid Reactive Substances (TBARS) value: The TBARS values were determined spectrophotometricaly according to Byun et al. (2001). Patty samples were analyzed for the optimum concentration of each ingredient. Homogenized patties sample $(2 \mathrm{~g})$ were taken and TBARS were extracted twice with $10 \mathrm{~mL}$ of $0.4 \mathrm{M}$ per chloric acid. Extracts were collected and made up to $25 \mathrm{~mL}$ with $0.4 \mathrm{M}$ per chloric acid and then centrifuged for $5 \mathrm{~min}$ at $1790 \mathrm{~g}$. After centrifugation, $1 \mathrm{~mL}$ of extract was poured into a glass stoppered test-tube. TBARS reagent $(5 \mathrm{~mL})$ was added and the extract was heated in a boiling water bath for $35 \mathrm{~min}$. After cooling in tap-water, the absorbance of the sample was read against the appropriate blank at $538 \mathrm{~nm}$. A standard curve was prepared using 1, 1, 3, 3Tetraethoxypropane (TEP).

Biogenic amines: Histamine, tyramine and putrescine were extracted as follows: $5 \mathrm{~g}$ of the sample were blended with $25 \mathrm{~mL} \mathrm{5 \%}$ trichloroacetic acid. Filtration was achieved using filter paper whatman No.1. About $5 \mathrm{~mL}$ of the extract were transferred into a suitable culture tube with $4 \mathrm{~g}$ $\mathrm{NaCl}$ and $1 \mathrm{~mL}$ of $50 \% \mathrm{Na} \mathrm{OH}$ then shacked for $2 \mathrm{~min}$. Centrifugation were carried out for $5 \mathrm{~min}$ at $5000 \times \mathrm{g}$ and the upper layer was transferred to $50 \mathrm{~mL}$ separating funnel. To the upper layer extract, $15 \mathrm{~mL}$ of $\mathrm{n}$-heptane were added and extracted 3 times with $1 \mathrm{~mL}$ portions of $0.2 \mathrm{~N} \mathrm{HCl}$. The extracts were collected in a glass stoppered tube and evaporated to dryness using water bath at $95^{\circ} \mathrm{C}$ with the aid of a gentle current of air. This was followed by the formation of Dansylamines as described by Maijala and Eerola (1993). Biogenic amines concentrations were determined according to Deabes (2000) using the HPLC. The HPLC system equipped with (Waters 600) delivery system. HPLC column: Reverse phase C 18 Nucleosil column $250 \times 4 \mathrm{~mm}, 10 \mu \mathrm{m}$ packing, (MachereyNagg1). The detection was performed using U.V detector (waters 486) at $254 \mathrm{~nm}$ wavelength using linear program of $25 \mathrm{~min}$ period and $1 \mathrm{~mL} \mathrm{~min}^{-1}$ constant solvent flow rate. Data were integrated and recorded using a Millennium Chromatography. Manger software 2010 (Waters, Milford MA 01757). 


\section{Microbial counts}

Aerobic Plate Ccount (APC): It was determined on nutrient agar medium as recommended by the American Public Health Associations for food stuff examination (APHA, 1992). The plates of different dilution were incubated at $37^{\circ} \mathrm{C}$ for $24-48 \mathrm{~h}$.

Mould and yeast counts: They were estimated on potatoes agar according to APHA (1992). The medium was acidified to $\mathrm{pH} 3.5$ by adding sterile $10 \%$ lactic acid solution, incubation was carried out at $25-28^{\circ} \mathrm{C}$ for $72 \mathrm{~h}$.

Statistical analysis: The conventional statistical methods were used to calculate means and standard deviations. All the measured were replicated three times and the data are presented as mean $\pm \mathrm{SD}$. The effects of natural antioxidant extracts addition and storage period were analyzed and the obtained data were subjected to analysis of variance (ANOVA) according to PC-STAT, Version I A Copyright 1985, the University of Georgia.

\section{RESULTS AND DISCUSSION}

Optimum concentration of natural plant extracts: The optimum concentrations of each of the four tested natural plant (jojoba, jatropha, ginseng and ginger) extracts are shown in Table 1. Potential antioxidant of these extracts was determined through TBARS analysis. The concentration range employed for each test extract screened was from $0-1.0 \%$. Doubling of employed test natural extracts addition rates were also employed in patties processing to be more effective for assessing extracts performance. Optimum test extract addition rates based on antioxidant activity identified levels were jojoba $(0.1 \%)$, Jatropha $(0.1 \%)$, ginseng $(0.25 \%)$ and ginger $(0.25 \%)$.

pH changes: The effect of the optimum concentration of natural plant extracts under investigation on the $\mathrm{pH}$ values of lamb patties stored at $4^{\circ} \mathrm{C}$ for 9 days is shown in Table 2. On 0 time the $\mathrm{pH}$ of the control and all tested samples had the same value (5.92). Control samples, generally had higher $\mathrm{pH}$ values than the other samples throughout the storage time. Over storage period the $\mathrm{pH}$ values of the control and tested lamp patties containing natural antioxidant extracts were significantly $(\mathrm{p}<0.05)$ increased gradually. During storage time (3-9 days) it was noticed that $\mathrm{pH}$ value of control samples was higher (6.29) than the other tested samples. At the 9th day lamb patties containing ginger extract (sample 4) had the higher $\mathrm{pH}$ value and patties containing ginseng extract (sample 3) was of the lower value. The increase in $\mathrm{pH}$ may be due to the accumulation of metabolites by bacterial
Table 1: Optimum concentration of natural plant extracts determined in lamb patties

\begin{tabular}{lccc}
\hline $\begin{array}{l}\text { Natural plant } \\
\text { extract }\end{array}$ & $\begin{array}{c}\text { Concentration } \\
\text { range } \\
\text { screened (\%) }\end{array}$ & $\begin{array}{c}\text { Optimum working } \\
\text { concentration } \\
\text { range (\%) }\end{array}$ & $\begin{array}{c}\text { Optimum } \\
\text { concentration } \\
\text { determined (\%) }\end{array}$ \\
\hline Jojoba & $0-1$ & $0.1-0.500$ & 0.10 \\
Jatropha & $0-1$ & $0.1-0.250$ & 0.10 \\
Ginseng & $0-1$ & $0.25-1.00$ & 0.25 \\
Ginger & $0-1$ & $0.25-1.00$ & 0.25 \\
\hline
\end{tabular}

Table 2: Effect of the optimum concentration of natural plant extracts on $\mathrm{pH}$ changes of lamb patties stored at $4^{\circ} \mathrm{C}$ for 9 days

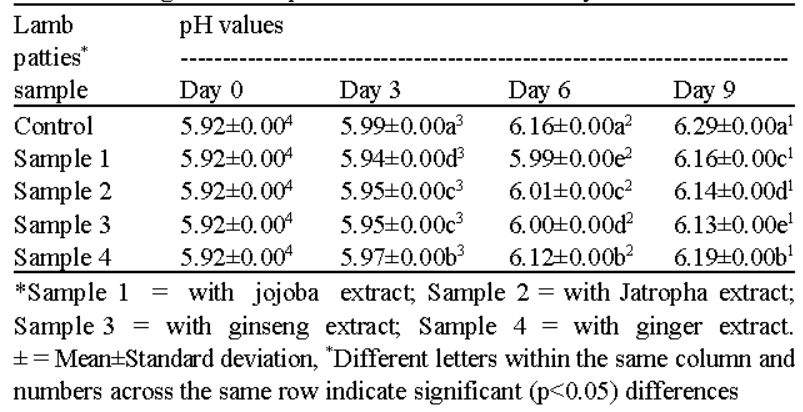

action in meat and deaminations of proteins (Jay, 1996). Similar findings in pork patties and in ground buffalo meat containing $\mathrm{BHA} / \mathrm{BHT}$ antioxidants during refrigerated and frozen storage, respectively have been reported by (McCarthy et al., 2001; Sahoo, 1995). Bacteria on exhaustion of stored glucose utilize amino acids released during protein breakdown and as a product of amino acid degradation, ammonia accumulates and $\mathrm{pH}$ rises (Gill, 1983).

Thiobarbituric Acid Reactive Substances (TBARS): The data shown in Table 3 show the changes of TBARS values in the lamb patties containing optimum concentration of the tested natural extracts stored at $4^{\circ} \mathrm{C}$ for 9 days. TBARS values were lower in all treated samples as compared to the control.

The screened natural extracts were effective as antioxidants and had lower TBARS values than the control samples over the days of storage. The effectiveness of used natural plant extracts as antioxidants inhibiting lipid oxidation throughout storage time could be listed in the following order of decreasing TBARS values: Ginseng>jatropha>jojoba>ginger. Results showed also that ginseng extract was the most effective antioxidant and ginger was of lowest effect. The highest TBARS values were noticed in control samples over time of storage while the lowest was in the tested samples containing ginseng. This can indicate that the optimum concentration of natural plant screened as antioxidant was effective against TBARS formation differently in their 
Table 3: Effect of the optimum concentration of natural plant extracts on TBARS values of lamb patties stored at $4^{\circ} \mathrm{C}$ for 9 days

\begin{tabular}{|c|c|c|c|c|}
\hline \multirow{2}{*}{$\begin{array}{l}\text { Lamb } \\
\text { patties } \\
\text { sample }^{*}\end{array}$} & \multicolumn{4}{|c|}{ TBARS values (mg malonaldehyde/kg meat) } \\
\hline & Day 0 & Day 3 & Day 6 & Day 9 \\
\hline Control & $0.158 \pm 0.0064$ & $0.264 \pm 0.009 \mathrm{a}^{3}$ & $0.494 \pm 0.024 \mathrm{a}^{2}$ & $0.626 \pm 0.006 \mathrm{a}^{1}$ \\
\hline Sampl 1 & $0.161 \pm 0.002^{4}$ & $0.175 \pm 0.005 \mathrm{c}^{3}$ & $0.326 \pm 0.004 b^{2}$ & $0.405 \pm 0.004 c^{1}$ \\
\hline Sampl 2 & $0.161 \pm 0.002^{4}$ & $0.174 \pm 0.004 c d^{3}$ & $0.324 \pm 0.004 \mathrm{c}^{2}$ & $0.404 \pm 0.001 \mathrm{c}^{1}$ \\
\hline Sampl 3 & $0.160 \pm 0.003^{3}$ & $0.165 \pm 0.005 \mathrm{~d}^{3}$ & $0.304 \pm 0.004 c^{2}$ & $0.393 \pm 0.003 \mathrm{~d}^{1}$ \\
\hline Sampl 4 & $0.161 \pm 0.003^{4}$ & $0.185 \pm 0.009 \mathrm{~b}^{3}$ & $0.345 \pm 0.004 \mathrm{~b}^{2}$ & $0.436 \pm 0.004 \mathrm{~b}^{1}$ \\
\hline
\end{tabular}

Table 4: Changes in Aerobic plate count of lamb patties stored at $4^{\circ} \mathrm{C}$ for 9 days

\begin{tabular}{|c|c|c|c|c|}
\hline \multirow{2}{*}{$\begin{array}{l}\text { Lamb } \\
\text { patties } \\
\text { sample* }^{*}\end{array}$} & \multicolumn{4}{|c|}{ Aerobic plate count $\left(\operatorname{Log~CFU~g}^{-1}\right)$} \\
\hline & Day 0 & Day 3 & Day 6 & Day 9 \\
\hline Control & $4.06 \pm 0.019^{4}$ & $4.996 \pm 0.012 \mathrm{a}^{3}$ & $6.23 \pm 0.010 \mathrm{a}^{2}$ & $7.57 \pm 0.027 \mathrm{a}^{1}$ \\
\hline Sample 1 & $4.06 \pm 0.019^{4}$ & $4.170 \pm 0.050 c^{3}$ & $4.30 \pm 0.019 c^{2}$ & $4.94 \pm 0.040 \mathrm{~b}$ \\
\hline Sample 2 & $4.06 \pm 0.019^{4}$ & $4.187 \pm 0.064 c^{3}$ & $4.30 \pm 0.031 c^{2}$ & $4.96 \pm 0.021 \mathrm{~b}$ \\
\hline Sample 3 & $4.06 \pm 0.019^{3}$ & $4.10 \pm 0.009 \mathrm{~d}^{3}$ & $4.18 \pm 0.019 \mathrm{~d}^{2}$ & $4.82 \pm 0.035 \mathrm{~b}$ \\
\hline Sample 4 & $4.33 \pm 0.479$ & $4.26 \pm 0.009 \mathrm{~b}$ & $4.45 \pm 0.035 b$ & $4.84 \pm 0.312 \mathrm{~b}$ \\
\hline
\end{tabular}

performance when incorporated in lamb patties. Estevez et al. (2004); Formanek et al. (2001); McCarthy et al. (2001) and Chen et al. (1999) reported that dried herbs and their essential oils were successfully used to reduce lipid oxidation in meat products. Polyphenolic extracts are excellent electron and proton donors and their intermediate radicals are quite stable due to electron delocalization phenomena and owing to the lack of positions attackable by $\mathrm{O}_{2}$ (Djenane et al., 2005).

In the present study, since the natural extracts used in preparing lamb patties contain bioactive substances e.g., phenolic compounds in Jatropha and ginger (El Diwani et al., 2009; Stoilova et al., 2007), flavonoids in jojoba (El-Halawany, 2002) and tritpenes saponins in ginseng (Fuzzati, 2004); these substances could cause inhibition of the chain reactions during lipid oxidation. Meat is prone to both microbial and oxidative spoilage and therefore it is desirable to use a preservative with both antioxidant and antimicrobial properties (Kanatt et al., 2008). The growing concern about safety of foods has led to the development of natural antimicrobials to control food-borne pathogen (Nevas et al., 2004).

Aerobic Plate Count (APC): Table 4 shows the effect of adding optimum concentrations of the natural plant extracts to the prepared lamb patties stored at $4^{\circ} \mathrm{C}$ for
Table 5: Changes in mould and yeast counts of lamb patties stored at $4{ }^{\circ} \mathrm{C}$ for 9 days

\begin{tabular}{|c|c|c|c|c|}
\hline \multirow{2}{*}{$\begin{array}{l}\text { Lamb } \\
\text { patties } \\
\text { sample* }\end{array}$} & \multicolumn{4}{|c|}{ Mould and yeast counts $\left(\operatorname{Log~CFU~g}^{-1}\right)$} \\
\hline & Day 0 & Day 3 & Day 6 & Day 9 \\
\hline
\end{tabular}

\begin{tabular}{lllll}
\hline Control & $2.32 \pm 0.019^{4}$ & $2.88 \pm 0.015 \mathrm{a}^{3}$ & $3.22 \pm 0.015 \mathrm{a}^{2}$ & $3.66 \pm 0.015 \mathrm{a}^{1}$
\end{tabular}

$\begin{array}{lllll}\text { Sample 1 } & 2.32 \pm 0.019^{4} & 2.43 \pm 0.047 \mathrm{c}^{3} & 2.52 \pm 0.025^{2} & 2.59 \pm 0.009 \mathrm{c}^{1}\end{array}$

$\begin{array}{lllll}\text { Sample 2 } & 2.32 \pm 0.019^{3} & 2.42 \pm 0.058 \mathrm{c}^{2} & 2.53 \pm 015 \mathrm{c}^{1} & 2.59 \pm 0.021 \mathrm{c}^{1}\end{array}$

$\begin{array}{lllll}\text { Sample } 3 & 2.32 \pm 0.019^{3} & 2.35 \pm 0.045 \mathrm{~d}^{3} & 2.43 \pm 0.019^{2} & 2.51 \pm 0.020 \mathrm{~d}^{1}\end{array}$

\begin{tabular}{lllll} 
Sample 4 & $2.32 \pm 0.019^{4}$ & $2.50 \pm 0.010 \mathrm{~b}^{3}$ & $2.60 \pm 0.021^{2}$ & $2.79 \pm 0.029 \mathrm{~b}^{1}$ \\
\hline
\end{tabular}

*Sample $1=$ with jojoba extract; Sample $2=$ with Jatropha extract; Sample 3 = with ginseng extract; Sample $4=$ with ginger extract. $\pm=$ Mean \pm Standard Deviation. ${ }^{*}$ Different letters within the same column and numbers across the same row indicate significant $(\mathrm{p}<0.05)$ differences

9 days on Aerobic Plate Count (APC). Remarkable increase was noticed in APC throughout storage, especially in the control sample at 6 and 9th days (from 6.23-7.57 $\mathrm{Log}_{\mathrm{CFU} \mathrm{g}}{ }^{-1}$, respectively. It has been reported by Insausti et al. (2001) that meat spoilage can not be said to occur until TVC counts reach $10^{6}-10^{8} \mathrm{CFU} \mathrm{g}^{-1}$ (limit of microbiological acceptability). In general, significant decrease was noticed for all tested patty samples in their aerobic plate count during storage period (3-9 days).

Worth to note that sample 3 (containing ginseng extract) was of the lowest APC and the patties with ginger extract (sample 4) was the highest compared the other samples. Thus, the results showed that Aerobic Plate Count (APC) decreased significantly with addition of the used natural extracts during the storage at $4^{\circ} \mathrm{C}$ for 9 days. Igbinosa et al. (2009) concluded that Jatropha curcas stem bark could be a potential source of active antimicrobial agents. Also, Jitoe et al. (1992) and Zia-ur-Rehman et al. (2003) found that ginger have antioxidant activity and effective antimicrobial.

Mould and yeast counts: Mould and yeast counts of the prepared lamb patties containing the optimum concentrations of the tested natural antioxidant during storage for 9 days at $4^{\circ} \mathrm{C}$ are shown in Table 5. It was observed that both the addition of the natural extracts and storage time had a significant effect on the mould and yeast counts.

The control samples had the highest mould and yeast counts all over the storage period. Their count numbers increased $(\mathrm{p}<0.05)$ from 2.32-3.66 ( $\left.\mathrm{Log} \mathrm{CFU} \mathrm{g}^{-1}\right)$ up to the 9 days of storage. In general, the patty samples (1-4) containing natural antioxidant extracts increased in their mould and yeast counts from 2.32 at 0 time to 2.59 , 2.59, 2.51 and 2.79 ( $\left.\operatorname{Log~CFU~g}^{-1}\right)$, respectively at the end of storage period. Lamb patties containing ginger extract (sample 4) were noticed to be of high mould and yeast counts. Higher reduction in mould and yeast counts was observed in the patties containing ginseng extract 
(sample 3) than in samples 1, 2 and 4 during the storage time. Meanwhile, samples containing jojoba and Jatropha ( 1 and 2) were of nearly the same mould and yeast counts. Thus, addition of the tested natural extracts reduced the mould and yeast counts in the prepared lamb patties. Spices and herbs, generally used in food stuffs for enhancing the flavor or color attributes have antimicrobial as well as antioxidant activity (Baydar et al., 2004; Sagdic and Ozcan, 2002; Yanishlieva and Marinova, 2001). So, the addition of ginseng extract was found to be more effective in reducing APC and mould and yeast counts in the tested lamb patties.

Biogenic Amines (BAs): The production of biogenic amines during storage or processing of food products is an extremely complex phenomenon depending on several variables such as the growth of microorganisms, several extrinsic and intrinsic factors during the manufacturing process such as formulation, some physico-chemical parameters and proteolytic and decarboxylase activities which interact with each others (Latorre-Moratalla et al., 2008; Suzzi and Gardini, 2003).

Table 6-8 show the effect of adding optimum concentrations of the used natural extracts to the prepared lamb patties stored at $4^{\circ} \mathrm{C}$ for 9 days on the formation of biogenic amines. Histamine, tyramine and putrescine $\left(\mathrm{mg} \mathrm{kg}^{-1}\right.$ ) were not detected in lamb patties at zero time of storage period. It was observed that storage time had a significant effect $(\mathrm{p}<0.05)$ up to 9 days at $4^{\circ} \mathrm{C}$ on the formation of all the estimated biogenic amines.

Histamine concentrations varied from 4.26$11.04 \mathrm{mg} \mathrm{kg}^{-1}$ in the control sample during storage at $4^{\circ} \mathrm{C}$ for 9 days. Data in Table 6 showed that on 3, 6 and 9 days histamine concentrations of all lamb patty samples were significantly $(\mathrm{p}<0.05)$ increased gradually. All natural plants extract were effective towards giving lower histamine concentrations than control samples over the storage period. Results showed ginseng extract was the most effective antioxidant while ginger was the less effective. Meanwhile, jatropha and jojoba extracts were nearly equal in their effectiveness for histamine formation.

The permitted level of tyramine in foods is $100-800 \mathrm{mg} \mathrm{kg}^{-1}$ while $1080 \mathrm{mg} \mathrm{kg}^{-1}$ is toxic (Shalaby, 1997). Tyramine concentrations in the present study were found in the safe range and within less than the permitted level. They varied in control and patties sample from $3.72-13.34 \mathrm{mg} \mathrm{kg}^{-1}$ during the 3-9 days of storage at $4^{\circ} \mathrm{C}$ (Table 7). The tyramine contents in the patties containing tested extracts were still less than the control level at 9th day. Using the tested natural antioxidants
Table 6: Effect of the optimum concentration of natural plant extracts on Histamine concentration in lamb patties stored at $4^{\circ} \mathrm{C}$ for 9 days

\begin{tabular}{|c|c|c|c|c|}
\hline \multirow{2}{*}{$\begin{array}{l}\text { Lamb } \\
\text { patties } \\
\text { samples }^{*}\end{array}$} & \multicolumn{4}{|c|}{ Histamine concentration $\left(\mathrm{mg} \mathrm{kg}^{-1}\right)$} \\
\hline & Day 0 & Day 3 & Day 6 & Day 9 \\
\hline Control & $\mathrm{ND}$ & $4.26 \pm 0.187^{33}$ & $6.84 \pm 0.127^{\mathrm{a} 2}$ & $11.04 \pm 0.147^{\mathrm{a} 1}$ \\
\hline Sample 1 & ND & $2.89 \pm 0.100^{\text {bc } 3}$ & $4.03 \pm 0.057^{\mathrm{c} 2}$ & $6.36 \pm 0.138^{c 1}$ \\
\hline Sample 2 & ND & $2.90 \pm 0.089^{\mathrm{bc} 3}$ & $3.98 \pm 0.068^{\mathrm{cd} 2}$ & $6.36 \pm 0.100^{c 1}$ \\
\hline Sample 3 & ND & $2.67 \pm 0.318^{\mathrm{c} 3}$ & $3.74 \pm 0.25^{\mathrm{d} 2}$ & $6.10 \pm 0.163^{\mathrm{d} 1}$ \\
\hline Sample 4 & $\mathrm{ND}$ & $3.14 \pm 0.136^{\mathrm{b} 3}$ & $4.35 \pm 0.125^{\mathrm{b} 2}$ & $7.04 \pm 0.064^{\mathrm{b} 1}$ \\
\hline \multicolumn{5}{|c|}{$\begin{array}{l}\text { *Sample } 1=\text { with jojoba extract; Sample } 2=\text { with Jatropha extract; } \\
\text { Sample } 3=\text { with ginseng extract; Sample } 4=\text { with ginger extract. } \\
\pm=\text { Mean } \pm \text { Standard Deviation. }{ }^{*} \text { Different letters within the same column and } \\
\text { letters numbers across the same row indicate significant }(p<0.05 \text { ) differences }\end{array}$} \\
\hline
\end{tabular}

Table 7: Effect of the optimum concentration of natural plant extracts on Tyramine concentrations in lamb patties stored at $4^{\circ} \mathrm{C}$ for 9 days Lamb Tyramine concentration $\left(\mathrm{mg} \mathrm{kg}^{-1}\right)$

\begin{tabular}{lllll} 
patties & & & & \\
samples $^{*}$ & Day 0 & Day 3 & Day 6 & Day 9 \\
\hline Control & ND & $5.38 \pm 0.170^{\mathrm{a} 3}$ & $7.84 \pm 0.140^{\mathrm{a} 2}$ & $13.34 \pm 0.555^{\mathrm{a} 1}$ \\
Sample 1 & ND & $3.94 \pm 0.055^{\mathrm{cd} 3}$ & $5.89 \pm 0.061^{\mathrm{cd} 2}$ & $8.04 \pm 0.074^{\mathrm{c} 1}$ \\
Sample 2 & ND & $4.02 \pm 0.031^{\mathrm{c} 3}$ & $5.95 \pm 0.045^{\mathrm{bc} 2}$ & $8.10 \pm 0.119^{\mathrm{c} 1}$ \\
Sample 3 & ND & $3.72 \pm 0.076^{\mathrm{d} 3}$ & $5.68 \pm 0.252^{\mathrm{d} 2}$ & $7.43 \pm 0.130^{\mathrm{d} 1}$ \\
Sample 4 & ND & $4.46 \pm 0.201^{\mathrm{b} 3}$ & $6.15 \pm 0.130^{\mathrm{b} 2}$ & $8.853 \pm 0.172^{\mathrm{b} 1}$ \\
\hline
\end{tabular}

*Sample $1=$ with jojoba extract; Sample 2 = with Jatropha extract; Sample 3 = with ginseng extract; Sample $4=$ with ginger extract. $\pm=$ Mean \pm Standard Deviation. *Different letters within the same column and numbers across the same row indicate significant $(p<0.05)$ differences

was found to significantly reduce $(\mathrm{p}<0.05)$ tyramine formation. The reduction of tyramine in lamb patty samples (1-4) containing the natural extracts under investigation relative to control sample was about $39.8 \%$ for jojoba, $39.4 \%$ for jatropha, $54.4 \%$ for ginseng and $33.7 \%$ for ginger extracts at the end of storage time.

Storage time had a significant effect $(\mathrm{p}<0.05)$ on tyramine formation, its concentrations in the tested patties samples increased significantly during storage period and reached at the 9th day to $8.04,8.10,7.43$ and $8.85 \mathrm{mg} \mathrm{kg}^{-1}$ in the four lamb patty samples $(1-4)$, respectively. Ginseng extract realized lower tyramine content $7.43 \mathrm{mg} \mathrm{kg}^{-1}$ thus showing marked effect towards this BA formation.

Eerola et al. (1997) observed that tyramine concentration in sausages increased during 7 days of storage at $4^{\circ} \mathrm{C}$. The reduction in tyramine formation by natural antioxidant extracts is important with respect to human health because tyramine causes migraine headaches increased blood pressure and an increase in noradrenalin as it has been previously reported by Ruiz-Capillas and Jimenez-Colmenero (2004).

The addition of the tested plant antioxidant extracts in preparation of the lamb patties stored at $4^{\circ} \mathrm{C}$ for 9 days affected significantly $(\mathrm{p}<0.05)$ the formation of putrescine. Its concentration increased up to $12.58,7.90,8.06$, 6.40 and $8.84 \mathrm{gm} \mathrm{kg}^{-1}$ in control and 1-4 patty 
Table 8: Effect of the optimum concentration of natural plant extracts on Putrescine concentrations in lamb patties stored at $4^{\circ} \mathrm{C}$ for 9 days

\begin{tabular}{|c|c|c|c|c|}
\hline \multirow{2}{*}{$\begin{array}{l}\text { Lamb } \\
\text { patties } \\
\text { samples" }\end{array}$} & \multicolumn{4}{|c|}{ Putrescine concentration $\left(\mathrm{mg} \mathrm{kg}^{-1}\right)$} \\
\hline & Day 0 & Day 3 & Day 6 & Day 9 \\
\hline Control & ND & $6.14 \pm 0.085^{\mathrm{a} 3}$ & $8.22 \pm 0.157^{a 2}$ & $12.58 \pm 0.407^{7^{1}}$ \\
\hline Sample 1 & ND & $4.16 \pm 0.115^{\mathrm{c} 3}$ & $5.53 \pm 0.231^{\mathrm{c} 2}$ & $7.90 \pm 0.096^{\mathrm{c} 1}$ \\
\hline Sample 2 & ND & $4.18 \pm 0.095^{\mathrm{c} 3}$ & $5.54 \pm 0.216^{c 2}$ & $8.06 \pm 0.081^{c 1}$ \\
\hline Sample 3 & ND & $3.42 \pm 0.126^{\mathrm{d} 3}$ & $4.81 \pm 0.165^{\mathrm{d} 2}$ & $6.40 \pm 0.180^{\mathrm{d} 1}$ \\
\hline Sample 4 & $\mathrm{ND}$ & $4.45 \pm 0.065^{b 3}$ & $6.25 \pm 0.122^{\mathrm{b} 2}$ & $8.84 \pm 0.140^{b 1}$ \\
\hline
\end{tabular}

samples, respectively at the end of storage period (Table 8). The highest putrescine concentration was observed in control sample while the lowest was for sample 3 containing ginseng extract. Thus, addition of the natural plant extracts was found effective for reducing the formation of putrescine. Ranking in decreasing order of the effectiveness of the used extracts on putrescine concentration in the lamb patty samples are: ginseng> jojoba $>$ jatropha $>$ ginger. This reduction could be also due to the antimicrobial activities of the natural extracts. Putrescine formation depends on the total aerobic count where a high total aerobic count results in high putresine formation (Ruiz-Capillas and Jimenez-Colmenero, 2004). Therefore, it can be stated that the addition of optimum concentration of the used natural plant extracts to lamb patties realized marked significant reduction in histamine, tyramine and putrescine formation.

\section{CONCLUSION}

Comparison of control and treated lamb patties samples during storage at $4^{\circ} \mathrm{C}$ for 9 days showed that addition of the investigated natural plant extracts was effective as antioxidant and anti microbial agents for improving the properties of the prepared lamb patties from quality and safety view point. Results showed, generally, ginseng extract was the most effective and ginger extract was the lowest.

Also, It was noticed that the optimum concentration of the investigated natural extracts were effective in reducing Aerobic Plate Count (APC) and mould and yeast counts and against biogenic amines (histamine, tyramine and putrescine) formation as well TBARS reduction; differently in their performance when incorporated in lamb patties. Effectiveness of the tested natural antioxidant extracts could be listed in the following order of decreasing TBARS value: Ginseng $>$ jatropha $>$ jojoba $>$ ginger.

\section{REFERENCES}

APHA, 1992. Compendium Methods for the Microbiological Examination of Foods. 2nd Edn., American Public Health Association, Washington, DC.

Aaby, K. and G. Skrede, 2003. Synthetic antioxidants control lipid oxidation in mechanically deboned turkey meat. Meat Sci., 65: 1147-1155.

Alma, M.H, A. Mavi, A. Yildirim, M. Digrak and T. Hirata, 2003. Screening chemical composition and in vitro antioxidant and antimicrobial activities of the essential oils from origanum syriacum growing in Turkey. Biol. Pharm. Bull., 26: 1725-1729.

Azaizeh, H., P. Ljubuncic, I. Portnaya, O. Said, U. Cogan and A. Bomzon, 2005. Fertilization-induced changes in growth parameters and antioxidant activity of medicinal plants used in traditional Arab medicine. Evid. Based Complement Alternt. Med., 2: 549-556.

Baydar, H., O. Sagdic, O. Gulcan and T. Karadogan, 2004. Antibacterial activity and composition of essential oils from origanum, thymbra, an satureja species with commercial importance in Turkey. Food Control, 15: 169-172.

Bozin, B., N. Mimica-Dukic, I. Samojlik and E.A. Jovin, 2007. Antimicrobial and antioxidant properties of rosemary and sage (Rosmarinus officinalis L. and Salvia officinalis L., Lamiaceae) essential oils. J. Agric. Food, 55: 7879-7885.

Breemen, R.B., C.R. Huang, Z.Z. Lu, A. Rimando, H.H.S. Fong and J.F. Fitzloff, 1995. Electrospray liquid chromatography mass spectrometry of ginsenosides. Analytical Chem., 67: 3985-3989.

Byun, M.W., J.W. Lee, C. Jo and H.S. Yook, 2001. Quality properties of sausage made with gamma-irradiated natural pork and lamb casing. Meat Sci., 59: 223-228.

Camo, J., J.A. Beltran and P. Roncales, 2008. Extension of the display life of lamb with an antioxidant active packaging. Meat Sci., 80: 1086-1091.

Chen, X., C. Jo, J.I. Lee and D.U. Ahn, 1999. Lipid oxidation, volatiles and color changes of irradiated pork patties as affected by antioxidants. J. Food Sci., 64: 16-19.

Deabes, M.M.Y., 2000. Studies on some biogenic amines in some meat and fish products with respect to other quality attributes. M.Sc. Thesis, Food Science and Technology Department, Faculty of Agriculture, Al-Azhar Univrsity, Cairo, Egypt.

Djenane, D., L. Montanes and P. Roncales, 2005. Nuevas perspectivas para la conservación natural de la carne. Eurocarne, 133: 153-180. 
Eerola, S., A.X. Sagues, L. Lilleberg and H. Aalto, 1997. 1997. Biogenic amines in dry sausage during shelf-life storage. Zeitunig Lebensmittel Fur. Unters Forsch. A., 205: 351-355.

El Diwani, G., S. El Rafie and S. Hawash, 2009. Protection of biodiesel and oil from degradation by natural antioxidants of Egyptian Jatropha. Int. J. Environ. Sci. Tech., 6: 369-378.

El-Halawany, A.M.A., 2002. Pharmacognostical study of simmondsia chinenisis (link) schneider family buxaceae (simmondsiaceae) cultivated in Egypt. M.Sc. Thesis, Pharmaceutical Science (Pharmacognosy), Pharmacognosy, Department, Faculty of Pharmacy, Cairo University.

Estevez, M. and R. Cava, 2006. Effectiveness of rosemary essential oil as an inhibitor of lipid and protein oxidation: Contradictory effects in different types of frankfurters. Meat Sci., 72: 348-355.

Estevez, M., D. Morcuende, J. Ventanas and R. Cava, 2004. Effect of the addition of sage and rosemary extracts on the oxidative stability of different types of liver pates. Proceedings of the 50th International Congress of Meat Science and Technology, Aug. 8-13, Helsinki, Finland, pp: 194-195.

Formanek, Z., J.P. Kerry, F.M. Higgins, D.J. Buckley, P.A. Morrissey and J. Farkas, 2001. Addition of synthetic and natural antioxidants to á-tocopheryl acetate supplemented beef patties: Effects of antioxidants and packaging on lipid oxidation. Meat Sci., 58: 337-341.

Fuzzati, N., 2004. Analysis methods of ginsenosides. J. Chromtography B., 812: 119-133.

Gill, C.O., 1983. Meat spoilage and evaluation of the potential storage life of fresh meat. J. Food Prot., 46: 444-452.

Gillis, C.N., 1997. Panax ginseng pharmacology: A nitric oxide link. Biochem. Pharmacol., 54: 1-18.

Gray, J.J., E.A. Gomaa and D.J. Buckley, 1996. Oxidative quality and shelf life of meats. Meat Sci., 43: 111-123.

Gubitz, G.M., M. Mittlebeach and M. Trabi, 1999. Exploitation of tropical oil seed plant Jatropha curcas L. Biosource Tech., 67: 73-82.

Hawash, S., N. Kamal, F. Zaher, O. Kenawi and G. El Diwani, 2009. Biodiesel fuel from Jatropha oil via non-catalytic supercritical methanol transesterification. Fuel., 88: 579-582.

Igbinosa, O.O., E.O. Igbinosa and O.A. Aiyegoro, 2009. Antimicrobial activity and phytochemical screening of stem bark extracts from Jatropha curcas (Linn). Afr. J. Pharm. Pharmacol., 3: 58-62.

Insausti, K., M.J. Beriain, A. Purroy, P. Alberti, C. Gorraiz, C. Alzueta and M.J. Alzueta, 2001. Shelf life of beef from local Spanish cattle breed stored under modified atmosphere. Meat Sci., 57: 273-781.
Jay, J.M., 1996. Antioxidants. In: Modern Food Microbiology, Jay, J.M. (Ed.). 4th Edn., CBS Publishers and Distributors, New Delhi, India, pp: 265-266.

Jeremiah, L.E., 2001. Packaging alternatives to deliver fresh meats using short- or long-term distribution. Food Res. Int., 34: 749-772.

Jitoe, A., T. Masuda, I.P. Tengah, D.N. Suprapta, I.W. Gara and N. Nakatan, 1992. Antioxidant activity of tropical ginger extract and analysis of the contained curcuminoids. J. Agric. Food Chem., 40: $1337-1340$.

Joyeux, M., F. Moitier and J. Fleurentin, 1995. Screening of antiradical, antilipo-peroxidant and hepatoprotective effects of nine plant extracts used in caribbean folk medicine. Phytother. Res., 9: 228-230.

Kanatt, S.R., R. Chander and A. Sharma, 2008. Chitosan and mint mixture: A new preservative for meat and meat products. Food Chem., 107: 845-852.

Kawamura, F., M. Okada, A. Futami and H. Fukuba, 1993. Antioxidative effect of ginger on the peroxidation of lard in boiled water. Part 2: Antioxidative effect of ginger extract. Nippon Kasei Gakkaishi, 44: 459-464.

Kikuzaki, H. and N. Nakatani, 1993. Antioxidant effects of some ginger constituents. J. Food Sci., 58: 1407-1410.

Lai, S.M., J.I. Gray, D.M. Smith, A. M. Booren, R.L. Crackel and D.J. Buckley, 1991. Effects of oleoresin rosemary, Tertiary butyl-hydroquinone and sodium tripoly-phosphate on the development of oxidative rancidity in restructured chicken nuggets. J. Food Sci., 56: 616-620.

Latorre-Moratalla, M.L., T. Veciana-Nogués, S. Bover-Cid, M. Garriga and T. Aymerich et al., 2008. Biogenic amine in traditional fermented sausage produced in selected European countries. Food Chem., 107: 912-921.

Lee, T.G., S.K. Williams, D. Slaon and R. Little, 1997. Development and evaluation of a chicken breakfast sausage manufactured with mechanically debond chicken meat. Poult. Sci., 76: 415-421.

Maijala, R.L.and S.H. Eerola, 1993. Contaminant Lactic acid bacteria of dry sausage produced histamine and tyramine. Meat Sci., 35: 387-395.

Makkar, H.P.S., K. Beaker, F. Sporer and M. Wink, 1997. Studies on nutritive potential and toxic constituents of different provenances of Jatropha curcas. J. Agric. Food Chem., 45: 3152-3157.

Mansour, E.H. and A.H. Khalil, 2000. Evaluation of antioxidant activity of some plant extracts and their application to ground beef patties. Food Chem., 69: 135-141. 
McCarthy, T.L., J.P. Kerry, J.F. Kerry, P.B. Lynch and D.J. Buckley, 2001. Evaluation of the antioxidant potential of natural food/plant extracts as compared with synthetic antioxidants and vitamin $\mathrm{E}$ in raw and cooked pork patties. Meat Sci., 58: 45-52.

Mielnik, M.B., S. Signe, E. Bjorg and S. Grete, 2008. Byproducts from herbs essential oil production as ingredient in marinade for turkey thighs. Food Sci. Technol., 41: 93-100.

Mothana, R.A.A. and U. Likdequist, 2005. Antimicrobial activity of some medicinal plants of island Soqotra. J. Ethanopharmcology, 96: 177-181.

Nevas, M., A.R. Korhonen, M. Lindrom, P. Turkki and H. Korkeala, 2004. Antibacterial efficiency of finnish spices essential oils against pathogenic and spoilage bacteria. J. Food Prot., 67: 199-202.

Nissen, L.R., D.V. Byrne, G. Bertelsen and L.H. Skibsted, 2004. The antioxidative activity of plant extracts in cooked pork patties as evaluated by descriptive sensory profiling and chemical analysis. Meat Sci., 68: 485-495.

Oladele, P.E. and A.A. Oshodi, 2007. Nutritional potential of berlandier nettle spurge (Jatropha catharetica) seed. Pak. J. Nutr., 6: 345-348.

Onal, A., 2007. A review: Current analytical methods for the determination of biogenic amines in foods. Food Chem., 103: 1475-1486.

Ramgahau, M.K., 2001. Ginseng: Crop and food research [Broad sheet]. New Zealand Institute for Crop and Food Research Ltd., A Crown Research Institute.

Reddy, V., A. Urooj and A. Kumar, 2005. Evaluation of antioxidant activity of some plant extracts and their application in biscuits. Food Chem., 90: 317-321.

Ruiz-Capillas, C. and F. Jimenez-Colmenero, 2004. Biogenic amines in meat and meat products. Crit. Rev. Food Sci. Nutr., 44: 489-499.

Sagdic, O. and M. Ozcan, 2002. Antibacterial activity of Turkish spice hydrolysis. Food Control, 14: 141-1 43.

Sahoo, J., 1995. Effect of preblending and vacuum packaging on the quality of ground buffalo meat. Ph.D.Thesis, Deemed University, IVRI, Izatnagar, India.

Salam, K.I., M. Ishloroshi and K. Samejima, 2004. Antioxidant and antimicrobial effects of garlic in chicken sausage. LWT-Food Sci. Technol., 37: 849-855.

Shalaby, A.R., 1997. Significance of biogenic amines to food safety and human health. Food Res. Int., 29: 475-490.
Shen, X.H., Y.P. Ren and Y. Chen, 2003. Detection of ginsenoside in health foods by HPLC. Chin. J. Health Lab. Technol., 5: 600-601.

Sievenpiper, J.L., J.T. Arnason, L.A. Leiter and V. Vuksan, 2003. Variable effects of American ginseng: a batch of American ginseng (Panax quinquefolius L.) with a depressed ginsenoside profile does not effect postprandial glycemia. Eur. J. Clin. Nutr. Metabolism, 57: 243-248.

Solomakos, N., A. Govaris, P. Koidis and N. Botsoglous, 2008. The antimicrobial effect of thyme essential oil, nisin, and their combination against Listria mono cyto genes in minced beef during refrigerated storage. Food Microbiol., 25: 120-127.

Stoilova, I., A. Krastanov, A. Stoyanova, P. Denev and S. Gargova, 2007. Antioxidant activity of a ginger extract (Zingiber officinale). Food Chem., 102: 764-770.

Suzzi, G. and F. Gardini, 2003. Biogenic amines in dry fermented sausages: A review. Int. J. Food Microbiol., 88: 41-54.

Tang, S., J.P. Kerr, D. Sheehan, D.J. Buckley and P.A. Morrissey, 2001. Antioxidative effect of added tea catechins on susceptibility of cooked red meat, poultry and fish patties to lipid oxidation. Food Res. Int., 34: 651-657.

Teague, R.K., S.L. Tynch, Jr. F.L. Jaksch and Jr. R.T. Maier, 2005. Compounds for altering food intake in humans. United States Patent 6852342. http://www.freepatentsonline.com/6852342.html.

Vinci, G. and M.L. Antonelli, 2002.. Biogenic amines: Quality index of freshness in red and white meat. Food Control, 13: 519-523.

Willcox, J.K., S.L. Ash and G.L. Catignani, 2004. Antioxidants and prevention of chronic disease. Crit. Rev. Food Sci., 44: 275-295.

Wood, J.D., M. Enser, A.V. Fisher, G.R. Nute, R.I. Richardson and P.R. Sheard, 1999. Manipulating meat quality and composition. Proc. Nutr. Soc., 58: 363-370.

Yanishlieva, N.V. and E.M. Marinova, 2001. Stabilization of edible oils with natural antioxidant. Eur. J. Lipid Sci. Technol., 103: 752-767.

Yanishlieva, N.V., E. Marinovaa and J. Pokorny, 2006. Natural antioxidants from herbs and spices. Eur. J. Lipid Sci. Technol., 108: 776-793.

Zia-ur-Rehman, A.M. Salariya and F. Habib, 2003. Antioxidant activity of ginger extract in sunflower oil. J. Sci. Food Agric., 83: 624-629. 